\title{
Neurotoxicity of Pneumolysin, a Major Pneumococcal Virulence Factor, Involves Calcium Influx and Depends on Activation of p38 Mitogen-Activated Protein Kinase ${ }^{1}$
}

\author{
Argyrios K. Stringaris, ${ }^{* 2}$ J ens Geisenhainer,* \\ Friederike Bergmann, ${ }^{+, 2}$ Christoph Balshüsemann,* Unaa Lee,* \\ Gregor Zysk, ${ }^{\ddagger}$ Timothy J. Mitchell, ${ }^{\S}$ Bernhard U. Keller, ${ }^{\dagger}$ \\ Ulrich Kuhnt, ${ }^{\mathbb{I}}$ J oachim Gerber,* Annette Spreer,* \\ Mathias Bähr,* Uwe Michel,* and Roland Nau*,3 \\ ${ }^{*}$ Department of Neurology and ${ }^{\dagger}$ Department of Neurophysiology, University of Göttingen, \\ 37075 Göttingen, Germany; ${ }^{\ddagger}$ Department of Medical Microbiology and Virology, University \\ of Düsseldorf, 40225 Düsseldorf, Germany; ${ }^{\S}$ Division of Infection and Immunity, University \\ of Glasgow, Glasgow, Scotland; and "Max Planck Institute for Biophysical Chemistry, 37075 \\ Göttingen, Germany
}

Received March 29, 2002; revised September 23, 2002; accepted for publication October 3, 2002

\begin{abstract}
Neuronal injury in bacterial meningitis is caused by the interplay of host inflammatory responses and direct bacterial toxicity. We investigated the mechanisms by which pneumolysin, a cytosolic pneumococcal protein, induces damage to neurons. The toxicity after exposure of human SH-SY5Y neuroblastoma cells and hippocampal organotypic cultures to pneumolysin was time- and dose-dependent. Pneumolysin led to a strong calcium influx apparently mediated by pores on the cell membrane formed by the toxin itself and not by voltage-gated calcium channels. Buffering of intracellular calcium with BAPTA-AM [1, 2-bis (o-aminophenoxy) ethane $\mathbf{N}, \mathbf{N}, \mathbf{N}^{\prime}, \mathbf{N}^{\prime}$-tetraacetic acid tetra(acetomethoxyl) ester] improved survival of neuronal cells following challenge with pneumolysin. Westem blotting revealed increased phosphorylation of p38 mitogen-activated protein kinase (p38 MAPK) as early as 30 min after challenge with pneumolysin. SB 203580, a potent and selective inhibitor of p38 MAPK, rescued human neuronal cells from pneumolysin-induced death. Inhibition of the mitochondrial permeability transition pore using bongkrekate and caspase inhibition also improved survival following challenge with the toxin. Modulation of cell death pathways activated by pneumolysin may influence the outcome of pneumococcal meningitis. ๑ 2003 Elsevier Science (USA)
\end{abstract}

Key Words: pneumolysin; p38 mitogen-activated protein kinase; calcium; meningitis; apoptosis.

\section{INTRODUCTION}

Despite introduction of effective antibacterial therapy more than 50 years ago, neurologic sequelae and

\footnotetext{
${ }^{1}$ Part of these data has been presented as a poster at the 54th Annual Meeting of the American Academy of Neurology in Denver Colorado.

${ }^{2}$ These authors contributed equally to this work.

${ }^{3}$ To whom correspondence should be addressed to Dr. Roland Nau, Department of Neurology, Georg-August-University, RobertKoch-Strasse 40, 37075 Göttingen, Germany. Fax: ++49 551398405. E-mail: mau@gwdg.de.
}

mortality from pneumococcal meningitis, the most frequent form of bacterial meningitis in adults, remain high (Quagliarello \& Scheld, 1992; Schuchat et al., 1997). Data from animal models of meningitis and postmortem studies of human brains point to neuronal cell death in the hippocampal formation as the pathologic substrate of neuropsychologic deficits among survivors of bacterial meningitis (Zysk et al., 1996; Nau et al., 1999; Wellmer et al., 2000; Nau \& Brück, 2002) Several lines of evidence suggest that bacteria may directly damage neurons (Braun et al., 
2002) or trigger an inflammatory burst involving the generation of toxic compounds by neutrophils and glial cells ultimately leading to neuronal cell death (Kim et al., 1995; Kim \& Täuber, 1996; van Furth et al., 1996). A detailed account of how bacteria might directly inflict damage to neurons is hitherto lacking.

Pneumolysin is a major virulence factor of pneumococci and belongs to a large family of highly homologous bacterial toxins (Rossjohn et al., 1998; Rubins \& Janoff, 1998). It causes injury to pulmonary alveolar epithelial cells (Rubins et al., 1993) and appears to be the causative factor of hearing loss and cochlear damage during experimental meningitis (Winter et al., 1997). The effects of pneumolysin are mediated by two mechanisms: binding to membranes leading to damage through pore formation, and activation of the complement system in a nonimmunospecific manner through direct interaction with the IgG domain Fc (Mitchell et al., 1991; Rossjohn et al., 1998).

The mitogen-activated protein kinase (MAPK) superfamily plays a critical role in signal transduction from the cell surface to the nucleus and becomes activated by a variety of stimuli ranging from growth factors to cytokines and cellular stress (Martin-Blanco, 2000; Ono \& Han, 2000). Depending on cellular context, the p38 MAPK appears to participate in both inflammatory responses and cell death (Harper \& LoGrasso, 2001; Junn \& Muradian, 2001; Maher, 2001; McLaughlin et al., 2001; Mota et al., 2001). Apparently p38 MAPK is central to both excitotoxic and nitric oxide-induced neuronal apoptosis (Kawasaki et al., 1997; Ghatan et al., 2000).

The purpose of this work was to determine whether pneumococci have a directly toxic effect on neuronal cells and to define the mechanisms involved. We have previously shown that apoptosis of neurons occurs in the dentate gyrus of the hippocampal formation in animals and humans with meningitis (Zysk et al., 1996; Nau et al., 1999). In this study we assessed the impact of pneumolysin, a pore forming bacterial toxin, on SH-SY5Y human neuronal cells and hippocampal organotypic cultures. To determine the signaling events following challenge with pneumolysin on neuronal cells, we assessed intracellular calcium $\left[\mathrm{Ca}^{2+}\right]_{\mathrm{i}}$ levels and activation of p38 MAPK. The specific inhibitor SB 203580 prevented cell death, indicating that activation of p38 MAPK is critical for pneumolysin-induced cell death.

\section{MATERIALS AND METHODS}

\section{Materials}

RPMI-1640 medium, fetal calf serum (FCS), and antibiotics were all from Biochrom, Berlin, Germany. Bongkrekate, $N$-acetylcysteine, thapsigargin, ionomycin, and Hoechst 33258 were purchased from Sigma, Deisenhofen, Germany. SB203580, N-benzyloxycarbonyl-Val-Ala-Asp-fluoromethyl-ketone (z-VAD-fmk), BAPTA-AM [1,2-bis(o-aminophenoxy) ethane- $N, N, N^{\prime}$, $N^{\prime}$-tetraacetic acid tetra(acetomethoxyl)ester] and rabbit antibodies to the phosphorylated and nonphosphorylated human p38 MAPK were from Calbiochem, San Diego, California, USA. Horseradish peroxidaseconjugated goat anti-rabbit antibodies were from Dako, Denmark. Enhanced chemiluminescence (ECLPlus) reagents were obtained from Amersham Pharmacia Biotech, UK, and fura-2 AM from Molecular Probes, Eugene, Oregon, USA, carbonyl cyanide $p$ (trifluoromethoxy) phenylhydrazone (FCCP) and cadmium chloride $\left(\mathrm{CdCl}_{2}\right)$ from Sigma, Deisenhofen, Germany. The glutamate receptor antagonists (RS)-3-(2carboxypiperazin-4-yl)-propyl-1-phosphonic acid (CPP) and 6-cyano-7-nitroquinoxaline-2,3-dione disodium (CNQX) were from Tocris (Tocris Cookson Ltd, Bristol, UK). All materials for in situ tailing were from Roche Molecular Biochemicals, Mannheim, Germany.

\section{Organotypic Hippocampal Cultures}

NMRI mice were bred at the animal care facility of the Max Planck Institute for Biophysical Chemistry, Goettingen, Germany. Five- to seven-day-old NMRI mice were decapitated and the hippocampal formations prepared and cut transversally with a McIlwain tissue chopper into slices $400 \mu \mathrm{m}$ thick under sterile conditions (Gähwiller, 1981; von Mering et al., 2001). Slices were kept in Grey's balanced salt solution (GBSS) supplemented with $36 \mathrm{mM}$ d-glucose at $4^{\circ} \mathrm{C}$ for $30 \mathrm{~min}$. Thereafter, slices were embedded in plasma clots on glass coverslips, which were then coagulated by the addition of thrombin. Coverslips were transferred to plastic culture tubes containing culture medium composed of 50\% Eagle's basal medium, 25\% Hanks' balanced salt solution, 25\% heatinactivated horse serum supplemented with glutamine $(1 \mathrm{mM})$, and $\mathrm{d}$-glucose $(36 \mathrm{mM})$. Culture tubes were placed in a roller device rotating at 10 revolutions $/ \mathrm{h}$ in an air-ventilated incubator at $36^{\circ} \mathrm{C}$. The medium was changed twice. After 7 days, cultures 
challenged with pneumolysin $(0.6$ or $6 \mu \mathrm{g} / \mathrm{ml}$ ) for $48 \mathrm{~h}$ were compared with those treated with medium only.

\section{Cell Culture}

SH-SY5Y human neuroblastoma cells were a generous gift from Dr. D. Isbrandt, Zentrum für Molekulare Neurobiologie, University of Hamburg, Germany, and were routinely maintained in RPMI-1640 supplemented with $10 \% \mathrm{FCS}$, penicillin $(100 \mathrm{IU} / \mathrm{ml})$, and streptomycin $(100 \mu \mathrm{g} / \mathrm{ml})$ at $37^{\circ} \mathrm{C}$ in a humidified atmosphere of $95 \%$ air and $5 \% \mathrm{CO}_{2}$.

\section{Measurement of Cell Viability}

Cell viability was determined by colorimetric monitoring of the conversion of 3-(4,5-dimethylthiazol-2-yl)-2,5-diphenyltetrazolium bromide (MTT) to formazan. SH-SY5Y cells were seeded into 96-well plates at a density of $10^{5} / \mathrm{cm}^{2}$. After stimulation with heat-inactivated bacteria or pneumolysin, culture medium was removed from the wells and cells were incubated for $30 \mathrm{~min}$ at $37^{\circ} \mathrm{C}$ followed by cell lysis and absorption measurement at $570 \mathrm{~nm}$ with a Dynatech spectrophotometer (Dynatech, Denkendorf, Germany). The validity of the MTT reduction assay was confirmed by comparison to results obtained from trypan blue exclusion assay. Both assays resulted in equal percentages of surviving cells after treatment with various toxic agents.

\section{Propidium lodide staining of OTCs Organotypic Hippocampal Cultures}

The vital dye propidium iodide (PI) was used to determine cell membrane integrity in organotypic hippocampal cultures (OTCs). After treatment with pneumolysin for $48 \mathrm{~h}$, medium was replaced by PI (25 $\mu \mathrm{g} / \mathrm{ml}$ dissolved in medium) followed by incubation for $3 \mathrm{~h}$ at $36^{\circ} \mathrm{C}$. Cultures were then photographed with an Axiophot fluorescence microscope (Zeiss, Oberkochen, Germany). Following fixation with formalin, cultures were again stained with PI and the pre- versus postfixation PI fluorescence ratio was calculated.

\section{Chromatin Staining}

SH-SY5Y cells were grown on coverslips at a density of $10^{5} / \mathrm{cm}^{2}$. After stimulation with various pneumolysin concentrations, cells were fixed with $4 \%$ paraformaldehyde (dissolved in PBS) for $30 \mathrm{~min}$, perme- abilized with methanol, and then rinsed three times with PBS and incubated with $120 \mathrm{ng} / \mathrm{ml}$ Hoechst 33258 dye for $30 \mathrm{~min}$. Stained chromatin was visualized using a Leica fluorescence microscope equipped with UV illumination.

\section{In Situ Tailing}

In situ tailing (IST) was performed as described (Stringaris et al., 1997) except that pretreatment with proteinase $\mathrm{K}$ was omitted. Coverslips were permeabilized with methanol and then incubated with tailing mixture containing terminal transferase and digoxigenin-labeled nucleotides for $1 \mathrm{~h}$ at $37^{\circ} \mathrm{C}$ according to the instructions of the manufacturer. After being blocked with fetal calf serum, cells were incubated with anti-digoxigenin antibody for $1 \mathrm{~h}$. The reaction was visualized using 4-nitrobluetetrazolium/5-bromo-4chloro-3-indolyl phosphate (NBT/BCIP). Counterstaining was performed with nuclear fast red aluminum hydroxide and results were visualized on a conventional Olympus microscope.

\section{Preparation of Pneumolysin}

Pneumolysin was purified as described (Paton et al., 1993). Recombinant toxin was overexpressed in Escherichia coli strain JM109. Bacteria were lysed by sonication, and pneumolysin was purified by hydrophobic and ion-exchange chromatography. Toxin purity was assessed by SDS-polyacrylamide gel electrophoresis followed by Coomassie blue staining which showed a single $52-\mathrm{kDa}$ band accounting for $95 \%$ of the protein.

\section{Western Blot Analysis}

Proteins were extracted as previously described (Tieu et al., 1999) with minor modifications: Cells were grown at a density of $10^{6} / \mathrm{cm}^{2}$ in six-well plates and treated with pneumolysin $(0.5 \mu \mathrm{g} / \mathrm{ml})$ or medium. Following stimulation, cells were removed from the plates and washed three times with PBS. Cell pellets were immediately frozen in liquid nitrogen and stored at $-80^{\circ} \mathrm{C}$ until protein extraction. Cellular protein was obtained by incubation for $20 \mathrm{~min}$ in lysis buffer [10 $\mathrm{mM}$ Tris buffer ( $\mathrm{pH} 7.4$ ) containing $0.15 \mathrm{mM} \mathrm{NaCI}, 5$ $\mathrm{mM}$ EDTA, $1 \%(\mathrm{v} / \mathrm{v})$ Triton X-100, and protease inhibitor cocktail tablets (Roche, Mannheim, Germany)] and then centrifuged at $20,800 \mathrm{~g}$ for $30 \mathrm{~min}$ at $4^{\circ} \mathrm{C}$. Alternatively, a rapid protein extraction protocol involving sonication of cell samples was used instead of ice-cold lysis. Cells were collected in lysis buffer con- 
taining $50 \mathrm{mM} \beta$-glycerol phosphate and sonified in a Branson sonifier.

The protein-containing supernatants were diluted 1:1 in sample buffer [0.16 $\mathrm{M} N, N$-bis(2-hydroxyethyl)glycine (Bicine), $0.36 \mathrm{M}$ bis(2-hydroxyethyl)imino-tris(hydroxymethyl)methane (Bis-Tris), 15\% $(\mathrm{w} / \mathrm{v})$ sucrose, $1 \%(\mathrm{w} / \mathrm{v})$ SDS, $0.05 \%(\mathrm{w} / \mathrm{v})$, bromphenol blue] and heated for $5 \mathrm{~min}$ at $95^{\circ} \mathrm{C}$. Electrophoresis was performed with $10 \% \mathrm{~T} / 5 \% \mathrm{C}$ gels (Wiltfang et al., 1991; Smirnov et al., 2000). Following electroblotting for $90 \mathrm{~min}$, polyvinyl difluoride (PVDF) membranes were heated for $3 \mathrm{~min}$ at $95^{\circ} \mathrm{C}$ and blocked for $2 \mathrm{~h}$ at room temperature (RT) in PBS containing $0.1 \%(\mathrm{v} / \mathrm{v})$ Tween (PBST) with 5\% (w/v) nonfat dry milk. Membranes were then incubated overnight at $4^{\circ} \mathrm{C}$ with primary antibody diluted 1:1000 in PBST. The next day, following washes, membranes were incubated for $1 \mathrm{~h}$ at RT with secondary antibody diluted 1:2000 in PBST. Membranes were washed, subsequently placed in $4 \mathrm{ml}$ of ECL-Plus chemiluminescent substrate, and then exposed to Konica X-Ray Medical Films (Konica Corp. Tokyo, Japan).

\section{Assessment of Pneumolysin Concentrations}

Pneumolysin was detected as a band at $53 \mathrm{kDa}$ and densitometrically quantitated using the software NIH Image 1.62. Recombinant pneumolysin was taken as a standard.

\section{Measurement of Intracellular Calcium Levels}

Changes in intracellular calcium $\left(\left[\mathrm{Ca}^{2+}\right]_{\mathrm{i}}\right)$ were measured in SH-SY5H cells attached to glass coverslips after 2-5 days in culture. Cell layers were incubated with RPMI-1640 containing $10 \mu \mathrm{M}$ fura-2 $\mathrm{AM}$ at $37^{\circ} \mathrm{C}$ for $30 \mathrm{~min}$. The RPMI-1640 medium used contains $0.846 \mathrm{mM} \mathrm{Ca}^{2+}$ (supplier's data). Cells were rinsed with RPMI or the appropriate bathing solutions and further incubated for $30 \mathrm{~min}$ at $37^{\circ} \mathrm{C}$ to allow complete deesterification.

Changes in $\left[\mathrm{Ca}^{2+}\right]_{\mathrm{i}}$ were measured using a CCD camera system (TILL Photonics, Martinsried, Germany) (Ladewig \& Keller, 2000). A computer-controlled monochromator (Polychrome II, TILL Photonics) was connected to an Axioscope microscope (Zeiss, Göttingen, Germany) via quartz fiberoptics and a minimum number of optical components for maximum fluorescence excitation (objective Achroplan W 63x, $0.9 \mathrm{~W})$. The CCD camera displayed 12-bit dynamics and an A/D converter with $12.5-\mathrm{MHz}$ sampling rate. Calcium changes in defined regions of interest (ROIs) were monitored online using the TILL Vision Software V3.3 (TILL Photonics, Martinsried, Germany). Background fluorescence was subtracted from the recorded values. The measured fluorescence ratio $[R]$ at wavelengths 360 and $390 \mathrm{~nm}$ was used to calculate $\left[\mathrm{Ca}^{2+}\right]_{\mathrm{i}}$ using the equation of Grynkiewicz et al. (1985). The $K_{\mathrm{d}}$ of fura-2 was experimentally determined as 224 nM (Tsien et al., 1982; Ladewig \& Keller, 2000). $R_{\min }$ and $R_{\max }$ were determined by exposing the cells to $25 \mu \mathrm{M}$ ionomycin in the presence of either $0 \mathrm{mM} \mathrm{Ca}^{2+}$ and $10 \mathrm{mM}$ EGTA or $10 \mathrm{mM} \mathrm{Ca}{ }^{2+}$.

Further analysis was performed off-line with the IGOR software (Wavemetrics, Lake Oswego, OR, USA). Bathing solutions were either RPMI-1640 or (in $\mathrm{mM}) \mathrm{NaCl} 140, \mathrm{KCl} 2, \mathrm{CaCl}_{2} 2.5, \mathrm{MgCl}_{2}$ 1, Hepes 10, glucose 40 , and bovine serum albumin $0.05 \%$ at $\mathrm{pH}$ 7.3. For nominally $\mathrm{Ca}^{2+}$-free solutions $\mathrm{MgCl}_{2}$ was substituted for $\mathrm{CaCl}_{2}$ without adding EGTA (Crudt et al., 1996).

\section{Animal Model of Experimental Pneumococcal Meningitis}

New Zealand white rabbits were kept at the Tierexperimentelle Einrichtung of the University of Göttingen. All measures were taken to reduce animal suffering to a minimum, and experiments were approved by the animal care committee of the University of Göttingen. Experimental pneumococcal meningitis was induced in rabbits as previously described (Zysk et al., 1996). In brief, a Streptococcus pneumoniae type 3 strain originally isolated from an adult with meningitis was used. After several passages in rabbits, infected cerebrospinal fluid was cultured on blood agar plates and bacteria were suspended in sterile saline solution. Anesthesia was induced by intramuscular injections of ketamine $(25 \mathrm{mg} / \mathrm{kg})$ and xylazine $(5 \mathrm{mg} / \mathrm{kg})$ and maintained with intravenous urethane for the entire duration of the experiment $(24 \mathrm{~h})$. Animals were inoculated intracisternally with $10^{6}$ colony-forming units (CFU) of S. pneumoniae. Cerebrospinal fluid was withdrawn $24 \mathrm{~h}$ later and immediately stored at $-20^{\circ} \mathrm{C}$. Animals were sacrificed using $75 \mathrm{mg}$ intravenous thiopental.

\section{Statistics}

Groups were compared by two-tailed parametric one-way ANOVA. $P$ values were adjusted for repeated testing by Bonferroni's posttest correction. A value of $P<0.05$ was considered statistically significant. 


\section{RESULTS}

\section{Purified Pneumolysin-Induced Cell Death in SH- SY5Y Human Neuroblastoma Cells and OTCs}

In preliminary experiments, application of heat-inactivated bacteria did not result in significant toxicity to neuronal SH-SY5Y cells.

Purified pneumolysin $(0.5-3 \mu \mathrm{g} / \mathrm{ml})$ was added to culture medium for up to $24 \mathrm{~h}$. Neurotoxicity of pneumolysin occurred in a dose- and time-dependent fashion (Fig. 1A); following $3 \mathrm{~h}$ of stimulation with 0.5 $\mu \mathrm{g} / \mathrm{ml}$ pneumolysin almost $40 \%$ of cells were dead. Chromatin staining of SH-SY5Y cells with pneumolysin revealed cells exhibiting chromatin condensation and fragmentation (Fig. 1B). Pneumolysin led to DNA fragmentation of human neuronal cells as exhibited by in situ tailing (Fig. 1C).

The effects of pneumolysin in a tissue context were investigated in hippocampal OTCs. Pneumolysin at a dose of $0.6 \mu \mathrm{g} / \mathrm{ml}$ induced cell death largely restricted to the dentate gyrus of the hippocampal formation (Fig. 1D).

\section{Pneumolysin Led to Perturbations of $\mathrm{Ca}^{2+}$ Homeostasis in Human Neuroblastoma Cells}

The minimum pneumolysin dose capable of leading to measurable cell death over a short period $(0.5 \mu \mathrm{g} /$ $\mathrm{ml}$ ) was used. SH-SY5Y human neuroblastoma cells were loaded with fura-2 AM and subsequently observed by CCD-camera imaging. Then, stimulation began with $0.5 \mu \mathrm{g} / \mathrm{ml}$ pneumolysin. Addition of RPMI medium to cells had no effect on intracellular $\mathrm{Ca}^{2+}$ concentrations (Fig. 2A). Approximately $10 \mathrm{~min}$ after addition of pneumolysin, nearly half of the recorded cells exhibited sudden rises of $\left[\mathrm{Ca}^{2+}\right]_{i}$ lasting $30 \mathrm{sec}$ to $4 \mathrm{~min}$. These were followed by a rapid decrease in $\left[\mathrm{Ca}^{2+}\right]_{i}$ (Fig. $2 \mathrm{~B}$ ). $\left[\mathrm{Ca}^{2+}\right]_{\mathrm{i}}$ initially returned to prestimulation levels, yet after subsequent peaks, $\left[\mathrm{Ca}^{2+}\right]_{\mathrm{i}}$ remained persistently elevated (Fig. 2B). Oscillations of intracellular calcium occurred repeatedly at high $\left[\mathrm{Ca}^{2+}\right]_{i}$ without reaching basal $\mathrm{Ca}^{2+}$ levels over a period of $60 \mathrm{~min}$.

\section{Calcium Oscillations Were due to Influx of Extracellular $\mathrm{Ca}^{2+}$}

Cells loaded with fura-2 AM were exposed to $\mathrm{Ca}^{2+}$ free bathing solution before the addition of $0.5 \mu \mathrm{g} / \mathrm{ml}$ pneumolysin. No alterations in $\left[\mathrm{Ca}^{2+}\right]_{\mathrm{i}}$ were observed (Fig. 3A). Conversely, when the bathing solution con- tained high concentrations $(2 \mathrm{mM})$ of extracellular $\mathrm{Ca}^{2+}$, high-pitched oscillations of $\left[\mathrm{Ca}^{2+}\right]_{i}$ were observed after pneumolysin challenge, but not after addition of medium only. The pneumolysin-induced amplitudes of $\mathrm{Ca}^{2+}$ oscillations in the presence of high extracellular $\mathrm{Ca}^{2+}$ concentrations by far exceeded those observed in RPMI culture medium.

To assess the contribution of intracellular $\mathrm{Ca}^{2+}$ stores to pneumolysin-induced calcium oscillations thapsigargin was used. Preincubation with $100 \mathrm{nM}$ thapsigargin led to a transient increase in $\left[\mathrm{Ca}^{2+}\right]_{i}$ which lasted approximately $10 \mathrm{~min}$. Thapsigargin did not abolish pneumolysin-induced $\mathrm{Ca}^{2+}$ oscillations (Fig. 3B). Addition of the protonophore FCCP, an uncoupler of the mitochondrial respiration, also did not inhibit pneumolysin-induced cytoplasmic calcium elevations (Fig. 3C).

To determine if $\mathrm{Ca}^{2+}$ influx resulted from opening of voltage-dependent $\mathrm{Ca}^{2+}$ channels, cells were loaded with $200 \mu \mathrm{M} \mathrm{CdCl}_{2}$. Blocking of calcium channels with cadmium did not abolish pneumolysin-induced elevations of $\left[\mathrm{Ca}^{2+}\right]_{\mathrm{i}}$ (Fig. 4A). Furthermore, selective blocking of NMDA and AMPA/kainate receptors with 10 $\mu \mathrm{M}$ CPP and $5 \mu \mathrm{M}$ CNOX, respectively, did not inhibit pneumolysin-induced elevations of intracellular calcium (Fig. 4B). Cells were also depolarized by adding $\mathrm{KCl}$ to a final concentration of $60 \mathrm{mM}$. The magnitudes of $\mathrm{KCl}(60 \mathrm{mM})$-evoked $\mathrm{Ca}^{2+}$ currents were lower than those observed after addition of pneumolysin by one order of magnitude (data not shown). Furthermore, when $\mathrm{KCl}(60 \mathrm{mM})$ was added to medium during pneumolysin stimulation, a further increase in $\mathrm{Ca}^{2+}$ amplitudes was observed. These results strongly suggest that the pneumolysin pore itself and not voltage-gated $\mathrm{Ca}^{2+}$ channels is responsible for $\mathrm{Ca}^{2+}$ influx after pneumolysin stimulation.

\section{Chelation of Intracellular Calcium with BAPTA- AM Reduced Neuronal Pneumolysin-Induced Cell Death}

Cells were preincubated with $10 \mu \mathrm{M}$ BAPTA-AM prior to challenge with $0.5 \mu \mathrm{g} / \mathrm{ml}$ pneumolysin or medium. BAPTA-AM pretreatment strongly enhanced survival of cells challenged with pneumolysin (Fig. 5). However, BAPTA-AM exerted toxic effects on SH-SY5Y cells as compared with medium-treated controls. Also, although buffering of intracellular calcium resulted in survival improvement of human neuronal cells as assessed by the MTT test it did not completely abolish morphologic alterations occuring after treatment with pneumolysin. 


\section{B}
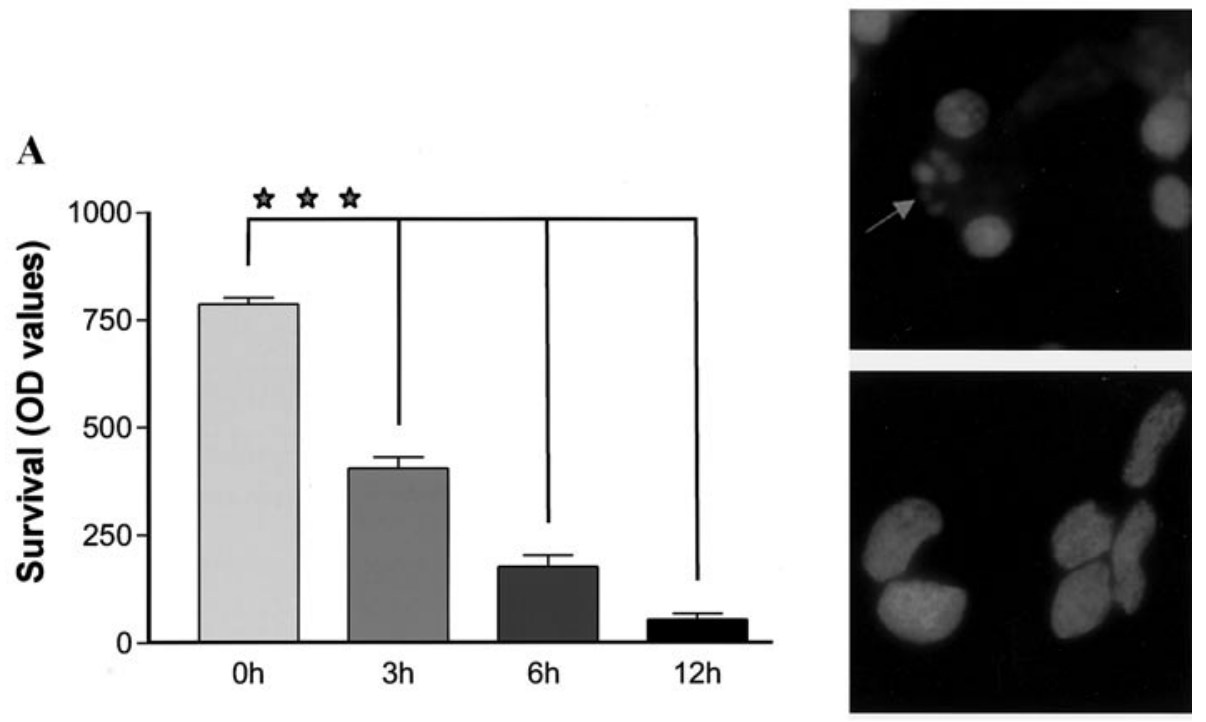

C
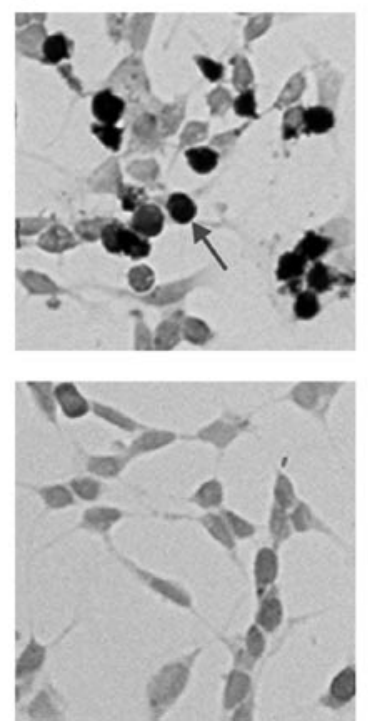

D
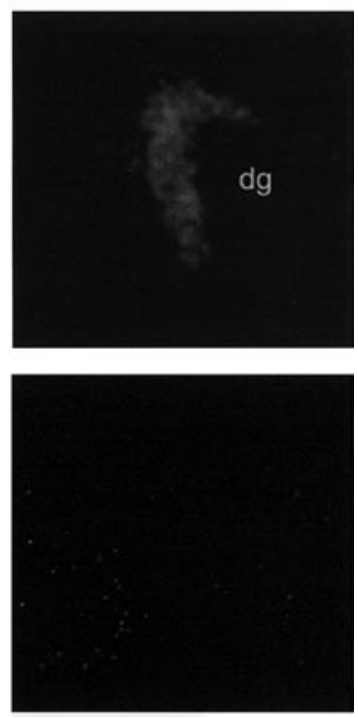

FIG. 1. Neuronal injury caused by pneumolysin. (A) Pneumolysin led to time-dependent toxicity on SH-SY5Y human neuronal cells as determined by the MTT test. Pneumolysin was added for the periods indicated at a final concentration of $0.5 \mu \mathrm{g} / \mathrm{ml}$ to cell culture medium. Data are expressed as means $\pm \mathrm{SD}$. ${ }^{* *} P<0.001$; for each condition $n=8$. (B) SH-SY5Y human neuronal cells undergoing pneumolysin-induced cell death showing morphologic features of apoptosis. After exposure to medium only (bottom) or $0.5 \mu \mathrm{g} / \mathrm{ml}$ (top) for $6 \mathrm{~h}$, cells were stained with the fluorescent chromatin dye Hoechst 33258. Pneumolysin-challenged as opposed to medium-treated cells displayed chromatin condensation and nuclear fragmentation. (C) In situ tailing (IST) of human neuronal cells. Cells were treated with either $0.5 \mu \mathrm{g} / \mathrm{ml} \mathrm{pneumolysin}$ or medium for $6 \mathrm{~h}$. Top: Cells with condensed nuclei were stained with IST after stimulation with pneumolysin (arrow points to a representative cell). Bottom: Medium-treated neuronal cells were IST negative. (D) Propidium iodide staining of hippocampal OTCs. Top: Propidium iodide uptake in the dentate gyrus of cultures challenged for $48 \mathrm{~h}$ with $0.6 \mu \mathrm{g} / \mathrm{ml}$ pneumolysin. Bottom: OTC treated with medium only showed virtually no dye uptake. 

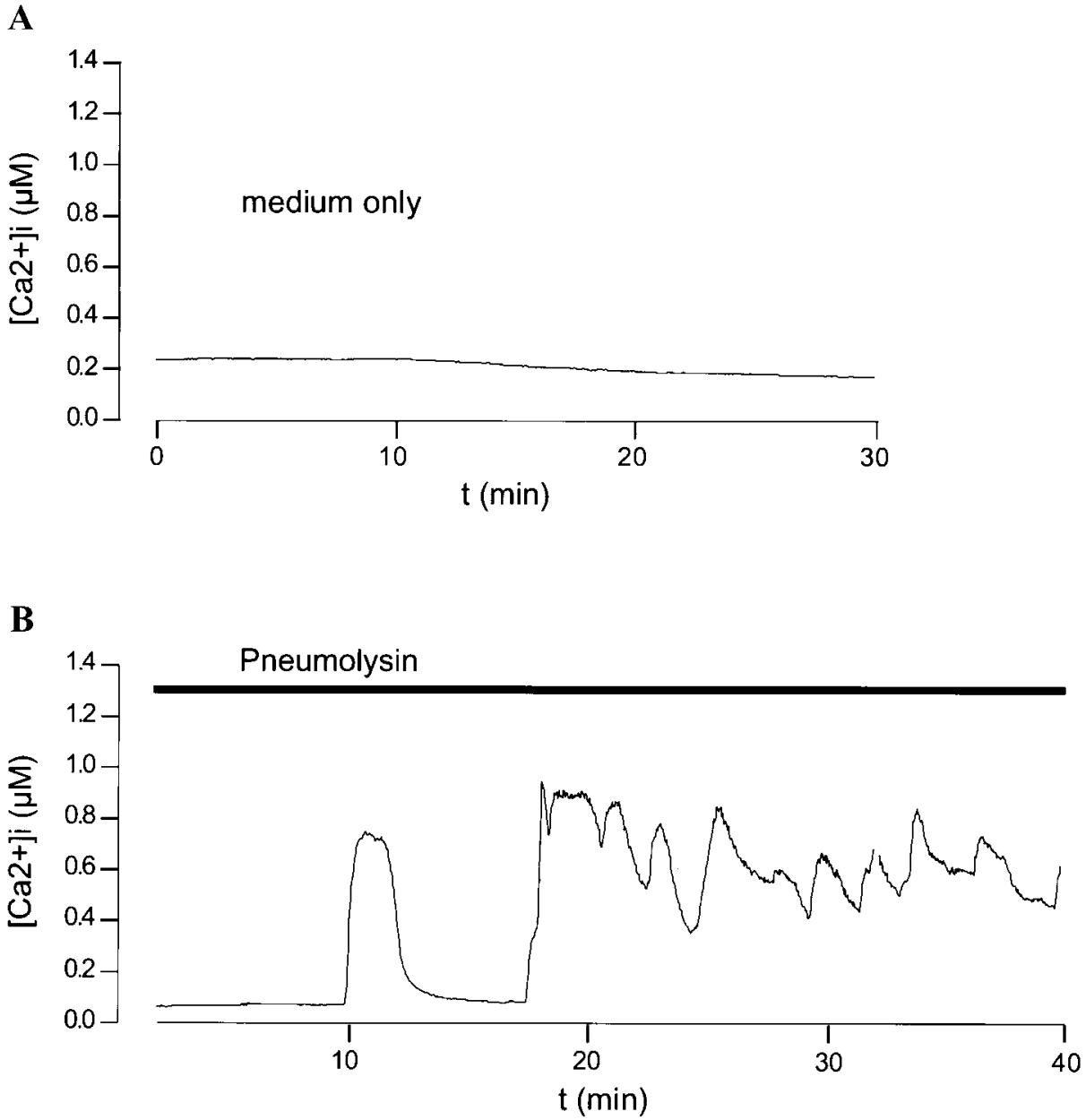

FIG. 2. Pneumolysin led to strong $\left[\mathrm{Ca}^{2+}\right]_{\mathrm{i}}$ increases in neuroblastoma cells. (A) Cell culture medium was added to cells as a negative control (a representative single-cell measurement out of 20 simultaneously recorded cells per observation field is depicted here; experiments performed in triplicate). (B) Pneumolysin $0.5 \mu \mathrm{g} / \mathrm{ml}$ was added to cells $2 \mathrm{~min}$ before start of measurement. Almost half of the cells showed a strong elevation of $\left[\mathrm{Ca}^{2+}\right]_{\mathrm{i}}$ in the micromolar range starting at approximately $10-20 \mathrm{~min}$ after addition of pneumolysin. Initially, $\left[\mathrm{Ca}^{2+}\right]_{\mathrm{i}}$ concentrations decreased but subsequent oscillations led to a persistent $\left[\mathrm{Ca}^{2+}\right]_{i}$ elevation. A representative single-cell measurement out of 25 simultaneously recorded cells per randomly chosen observation area is depicted here. Experiments were performed in quadruplicate.

\section{Activation p38 MAPK Was Important in Pneumolysin Induced Cell Death}

Western blotting experiments using a phospho-specific p38 MAPK antibody revealed p38 MAPK phosphorylation as early as $30 \mathrm{~min}$ after stimulation, with pneumolysin increasing steadily thereafter (Fig. 6B).

Cells were incubated with the selective inhibitor of p38 MAPK, SB 203580, in the presence of pneumolysin. Near-complete suppression of cell death was achieved when cells were examined $3 \mathrm{~h}$ following stimulation with pneumolysin. When the effects of p38 MAPK inhibition were assessed $12 \mathrm{~h}$ following co-incubation of SB 203580 and pneumolysin, approx- imately $60 \%$ of cells were still alive compared with less than $10 \%$ of those treated with pneumolysin only (Fig. $6 \mathrm{~A})$.

\section{Effects of Inhibition of the Mitochondrial Permeability Transition and Caspase Inhibition on Pneumolysin-Induced Cell Death}

Bongkrekate is known to inhibit the adenine nucleoside translocator, a protein component of the permeability transition pore complex at the inner mitochondrial membrane. Cotreatment of SH-SY5Y cells with bongkrekate resulted in significant protection from 
A

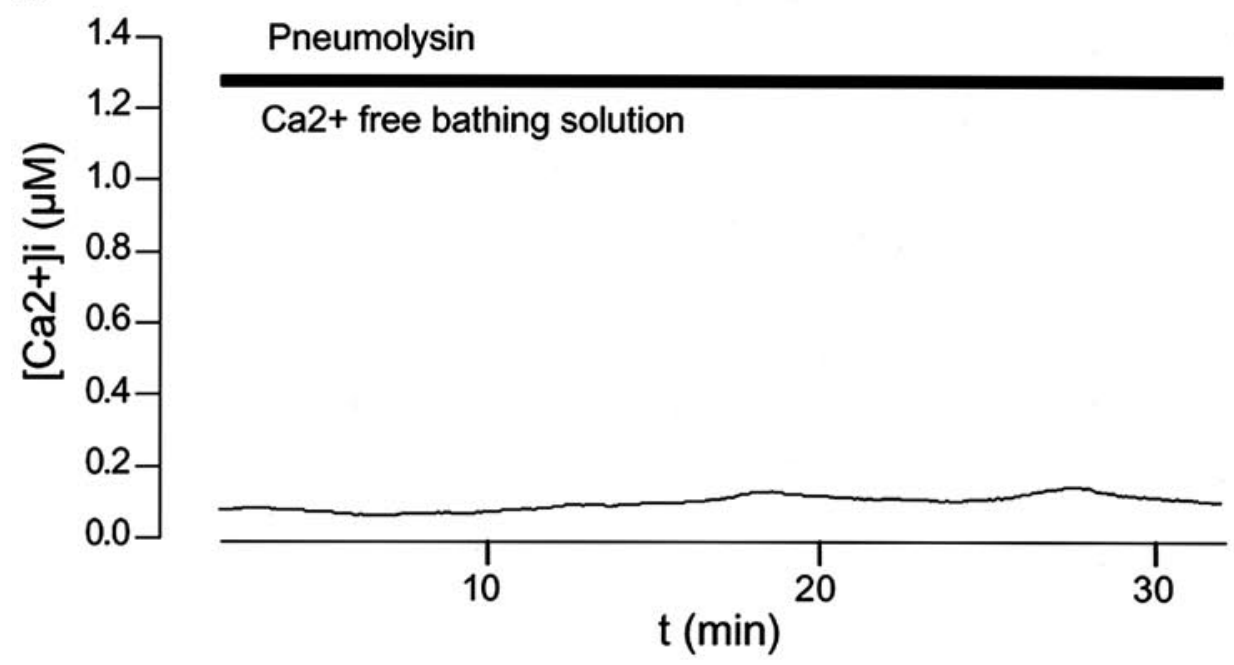

B

Thapsigargin (100 nM)

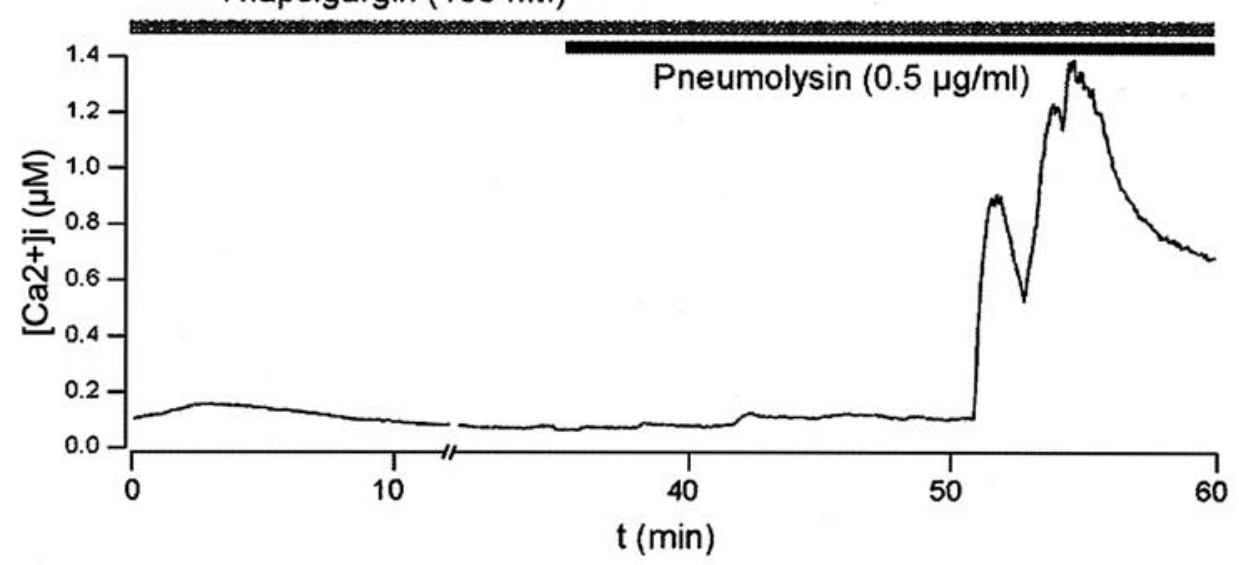

C

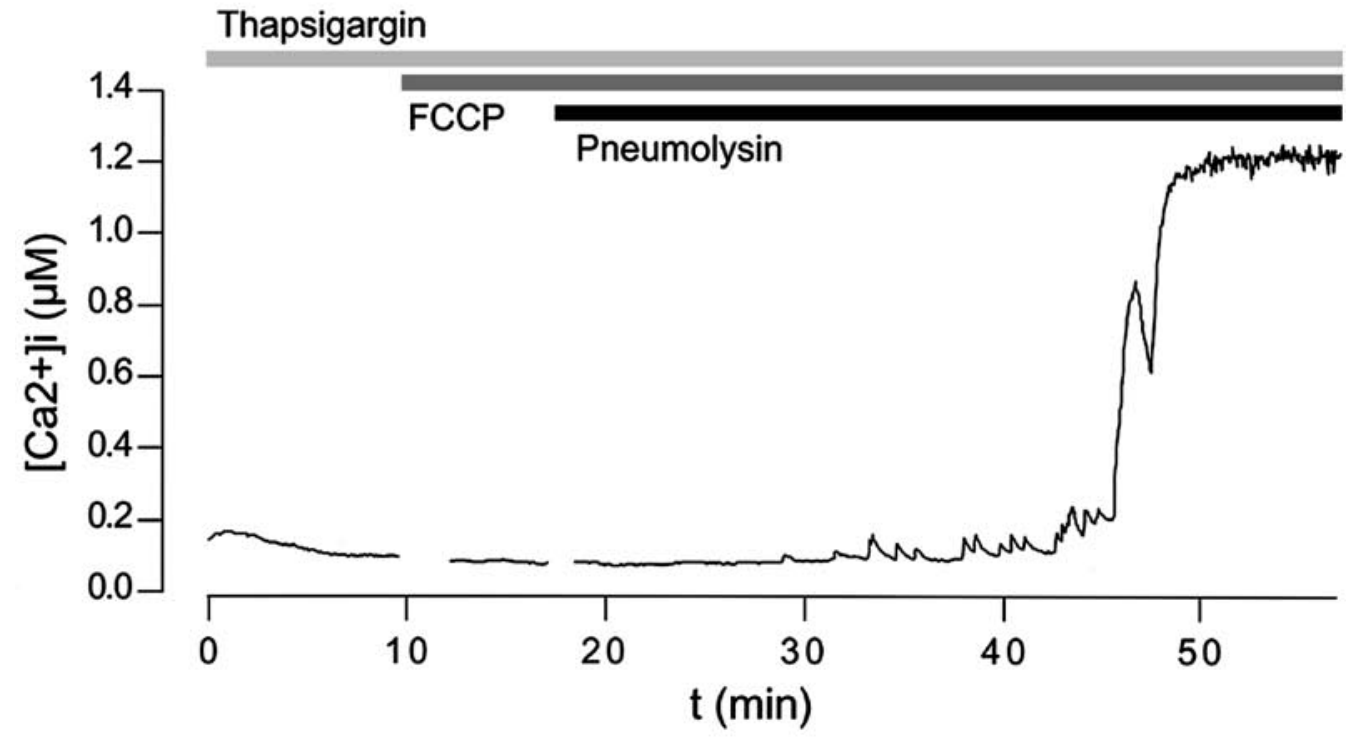


A

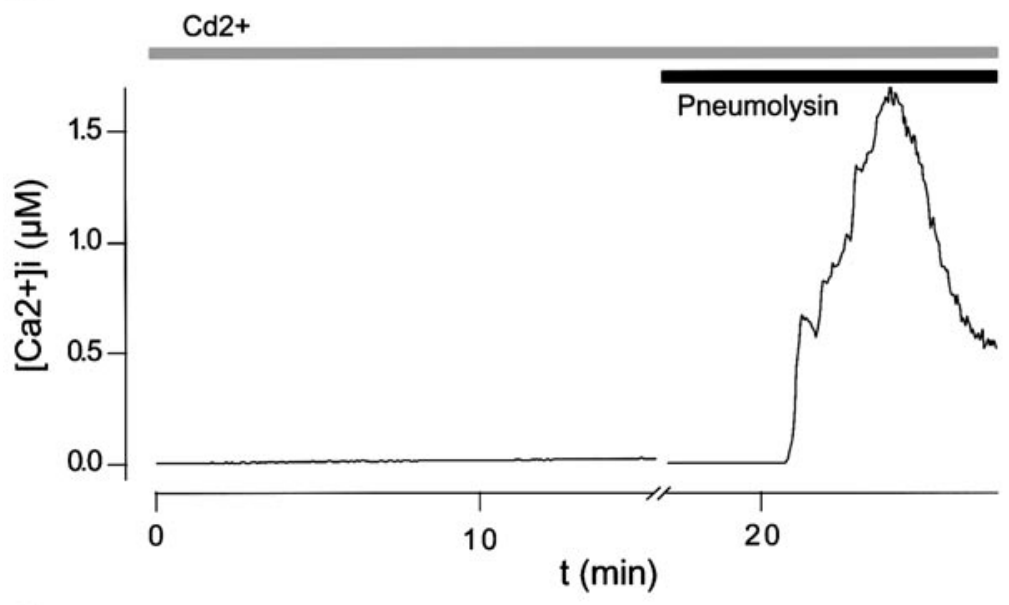

B

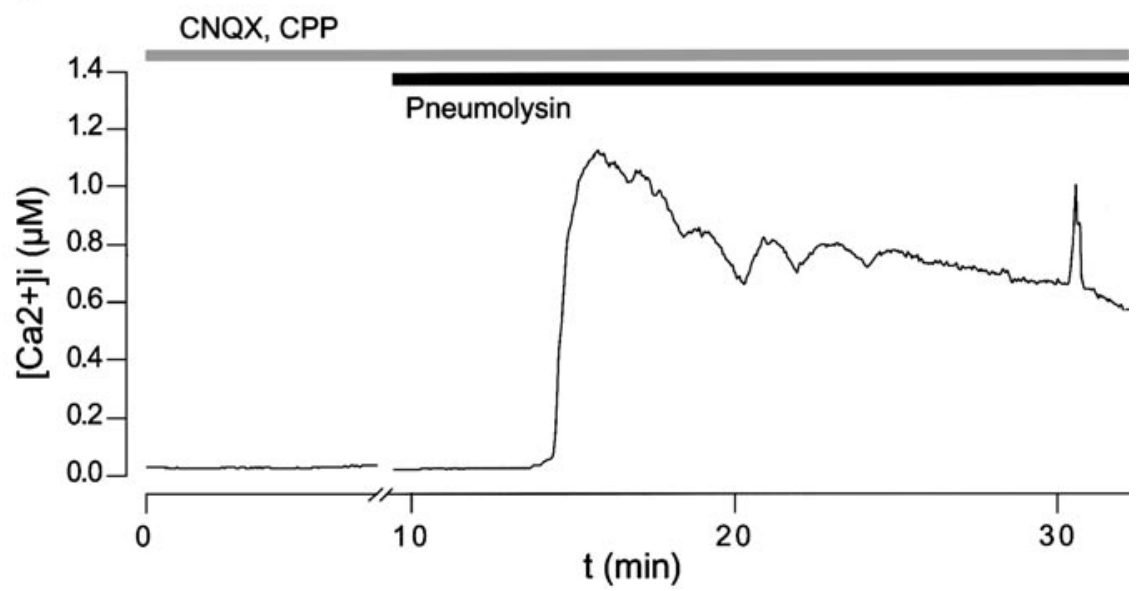

FIG. 4. Calcium influx was not mediated by voltage-sensitive $\mathrm{Ca}^{2+}$ channels or ionotropic glutamate receptors. (A) The addition of $\mathrm{CdCl} \mathrm{C}_{2}$ (200 $\mu \mathrm{M})$ to block voltage-gated $\mathrm{Ca}^{2+}$ channels did not affect pneumolysin-induced rises in $\left[\mathrm{Ca}^{2+}\right]_{\mathrm{i}}$. (B) Cells were incubated with $\mathrm{CNQX}(5 \mu \mathrm{M})$ and $\mathrm{CPP}(10 \mu \mathrm{M})$ to block ionotropic glutamate receptors. Basal calcium levels remained unaffected. The pneumolysin-induced increase in [Ca $\left.{ }^{2+}\right]_{\mathrm{i}}$ was not inhibited (representative measurement out of 15 simultaneously recorded cells in a randomly chosen observation area; experiments performed in duplicate).

FIG. 3. In SH-SY5Y human neuronal cells $\left[\mathrm{Ca}^{2+}\right]_{\mathrm{i}}$ increase was due to influx of extracellular calcium and not to mobilization of intracellular stores. (A) Stimulation with $0.5 \mu \mathrm{g} / \mathrm{ml}$ pneumolysin (Ply) in the presence of $\mathrm{Ca}^{2+}$-free bathing solution. No significant $\left[\text { Ca }{ }^{2+}\right]_{\mathrm{i}}$ changes were observed (representative single-cell measurement out of 15 cells recorded per randomly chosen observation field; experiments performed in triplicate). (B) Incubation of human neuronal cells with thapsigargin prior to treatment with pneumolysin. Intracellular Ca ${ }^{2+}$ stores were depleted by preincubation with $100 \mathrm{nM}$ thapsigargin for $30 \mathrm{~min}$, before $0.5 \mu \mathrm{g} / \mathrm{ml}$ pneumolysin (Ply) was added to the cells. Nearly $50 \%$ of the cells showed a strong elevation of $\left[\mathrm{Ca}^{2+}\right]_{i}$ in the micromolar range starting 10-15 min after addition of pneumolysin. Again the initial decrease was followed by persistently elevated $\left[\mathrm{Ca}^{2+}\right]_{i}$ levels. A representative single-cell measurment out of 24 cells recorded is shown. Thapsigargin alone induced a transient $\left[\mathrm{Ca}^{2+}\right]_{\mathrm{i}}$ elevation in the range of $100 \mathrm{nM}$ lasting approximately 10 min. Experiments were performed in duplicate. (C) Intracellular $\mathrm{Ca}^{2+}$ stores were depleted by preincubation with $100 \mathrm{nM}$ thapsigargin and $1 \mu \mathrm{M}$ FCCP for 20 and 5 min, respectively, before $0.5 \mu \mathrm{g} / \mathrm{ml}$ pneumolysin (Ply) was added to cells (representative measurement out of 15 simultaneously recorded cells in a randomly chosen observation area). Nearly half of the cells recorded showed a strong elevation of $\left[\mathrm{Ca}^{2+}\right]_{\mathrm{i}}$ in the micromolar range starting after addition of pneumolysin. Again the initial decrease was followed by persistently elevated $\left[\mathrm{Ca}^{2+}\right]_{\mathrm{i}}$ levels. Experiments were performed in triplicate. 


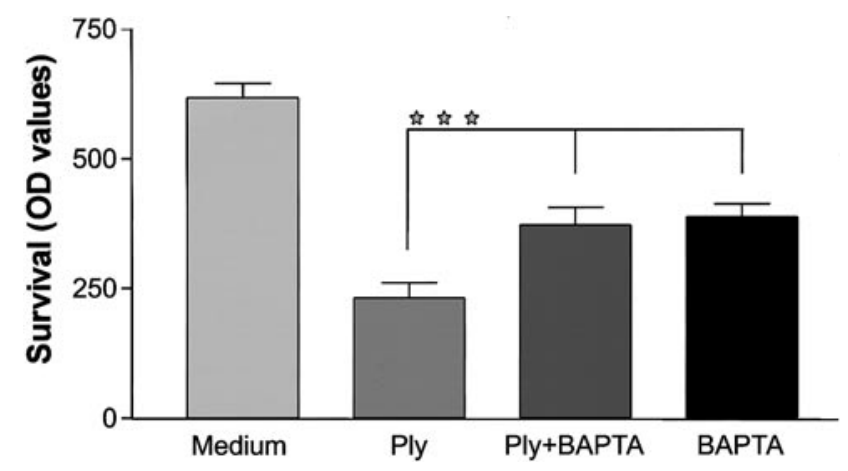

FIG. 5. Chelation of intracellular calcium with BAPTA-AM protected human neuronal cells from pneumolysin-induced toxicity. Cells were treated with either medium, or $0.5 \mu \mathrm{g} / \mathrm{ml}$ pneumolysin for $4 \mathrm{~h}$, or $0.5 \mu \mathrm{g} / \mathrm{ml}$ pneumolysin for $4 \mathrm{~h}$ after pretreatment of cells for 30 min with $10 \mu \mathrm{M}$ BAPTA-AM (BAPTA) or BAPTA-AM alone and assessed using the MTT test. BAPTA-AM reduced neuronal cell death caused by pneumolysin. Data presented as means \pm SD). ${ }^{* * *} P<0.001$. There was no statistical difference between cells treated with BAPTA only and those treated with both BAPTA and pneumolysin. BAPTA-AM alone was moderately toxic on SH-SY5Y cells. The difference between cells treated with medium and those treated with either both BAPTA and pneumolysin or BAPTA alone was also significant $(P<0.001 ; n=8$ for each condition, experiments performed in duplicate).

pneumolysin cytotoxicity as assessed by the MTT reduction assay (Fig. 7) and trypan blue exclusion. Phase-contrast microscopy of cells revealed that coincubation with bongkrekate also prevented morphologic alterations seen after treatment with pneumolysin alone.

Co-incubation of cells with the polycaspase inhibitor $\mathrm{z}$-VAD-fmk also exerted significant protection against challenge with pneumolysin as determined by the MTT reduction assay (Fig. 7). However, cells displayed morphologic alterations (shrinkage of cell bodies and loss of neurites) similar to those seen after exposure to pneumolysin alone.

\section{Pneumolysin Was Present in the CSF of Animals with Experimental Pneumococcal Meningitis}

In experimental pneumococcal meningitis $24 \mathrm{~h}$ after intracisternal injection of $10^{6}$ CFU S. pneumoniae, CSF concentrations of pneumolysin up to approximately $4.34 \mu \mathrm{g} / \mathrm{ml}$ were measured by Western blotting (Fig. 8). These data demonstrate that pneumolysin is present in the CSF at concentrations comparable to those used in our present study.

\section{DISCUSSION}

Brain damage in bacterial meningitis appears to be caused by the interplay of host inflammatory responses and direct toxicity of bacteria. Although the role of the inflammatory burst triggered by bacteria in the CNS has been extensively studied (Zysk et al., 1996; Braun et al., 1999b; Schmidt et al., 2001; Nau \& Brück, 2002), the mechanisms by which bacteria may directly damage neurons are poorly understood.

In this study we show that pneumolysin, a cytoplasmic pneumococcal protein, led to a time-dependent toxicity to human neuronal cells. This was accompanied by early cell shrinkage and the appearance of

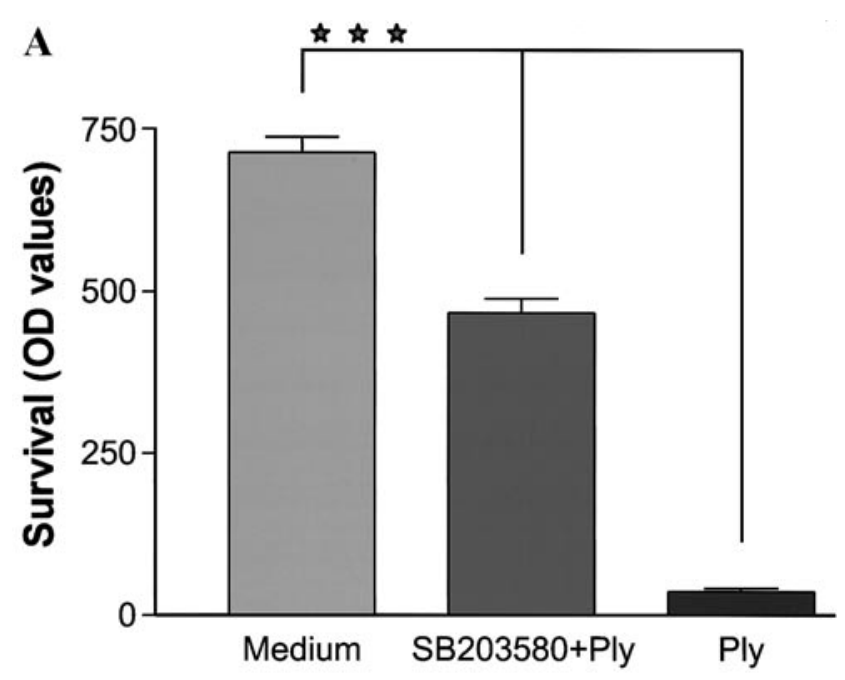

B

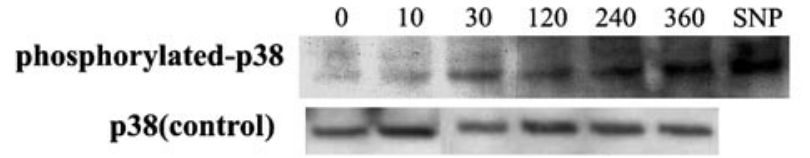

FIG. 6. Pneumolysin-induced cell death depended on activation of p38 MAPK. (A) MTT test of cells exposed to either medium or 0.5 $\mu \mathrm{g} / \mathrm{ml}$ pneumolysin (Ply) in the presence or absence of SB 203580 $(20 \mu \mathrm{M})$ for $12 \mathrm{~h}$. There was improved survival for cells co-incubated with SB 203580 and pneumolysin as compared with those treated with pneumolysin alone. data presented as means $\pm \mathrm{SD}$; ${ }^{* * *} P<0.001, n=8$ for each condition. At $12 \mathrm{~h}$ after treatment with pneumolysin protection by SB 203580 was not complete, however at earlier time points (3, 6, 9 hours) protection was nearly $100 \%$. (B) Western blotting detecting phosphorylated (top) and nonphosphorylated (bottom) p38 MAPK at the indicated periods following pneumolysin $(0.5 \mu \mathrm{g} / \mathrm{ml})$ stimulation. Assessment of the nonphosphorylated p38 MAPK levels was performed to ensure that equal amounts of total p38 MAPK were present at each time point. Samples of cells treated for $24 \mathrm{~h}$ with sodium nitroprusside (SNP) served as positive controls. Experiments performed in quadruplicate. 


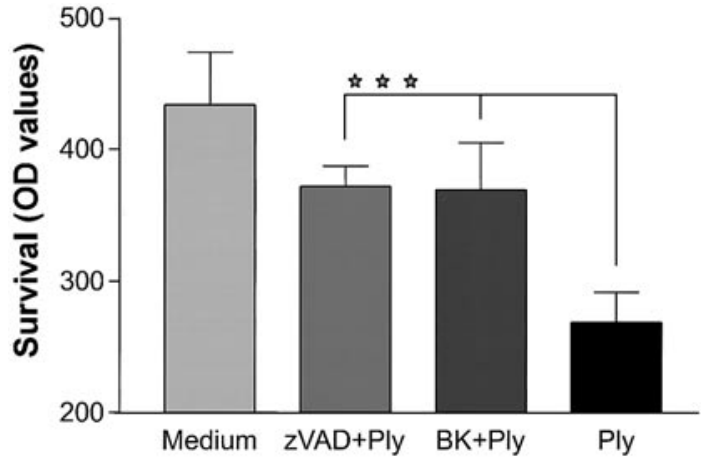

FIG. 7. Inhibition of mitochondrial permeability transition and caspase activity rescued SH-SY5Y cells from pneumolysin-induced toxicity. Cells were incubated with medium only or with $0.5 \mu \mathrm{g} / \mathrm{ml}$ pneumolysin in the presence or absence of either $20 \mu \mathrm{M} \mathrm{z}$-VAD-fmk (z-VAD) or $20 \mu \mathrm{M}$ bongkrekate (BK) for $4 \mathrm{~h}$. Asterisks denote statistically significant differences between cells stimulated with pneumolysin and cells co-incubated with pneumolysin in the presence of either $\mathrm{z}-\mathrm{VAD}$ or BK Results expressed as means $\pm \mathrm{SD} ; P<$ $0.001, n=8$ for each condition. There was also a statistically significant difference between medium-treated cells and those treated with pneumolysin in the presence of either z-VAD-fmk or bongkrekate $(P<0.05$; experiments performed in triplicate).

nuclear alterations and DNA fragmentation in chromatin stains and by in situ tailing, suggesting apoptosis. In agreement with previous studies (Kim et al., 1995; Kim \& Täuber, 1996) heat-inactivated bacteria did not possess significant neurotoxicity on isolated neuronal cells, whereas the proinflammatory properties, probably mediated by cell wall components, were preserved in heat-inactivated pneumococci. Pneumolysin is released mainly during autolysis of bacteria (Rossjohn et al., 1998), and its mode of action requires conformational integrity. Its toxicity was overlooked when heat inactivation was applied. We next evalu- ated whether pneumolysin is also toxic to neurons in a tissue context. To this end hippocampal organotypic cultures of mice were used. Challenge with low concentration pneumolysin resulted in cell death restricted mainly to the dentate gyrus of the hippocampal formation. Surrounding tissue was largely spared from pneumolysin toxicity. Very small doses of pneumolysin $(0.5-0.6 \mu \mathrm{g} / \mathrm{ml})$ were required for damage of both isolated neuronal cells and OTCs. This is more than one magnitude lower than concentrations (10-30 $\mu \mathrm{g} / \mathrm{ml}$ ) required for similar effects on human microvascular cells (Zysk et al., 2001) and argues for a particular susceptibility of neurons to pneumolysin.

Pneumolysin binds to cholesterol on membranes where it oligomerizes into ring-shaped structures with subsequent pore and vesicle formation within the bilayer (Bonev et al., 2001; Gilbert et al., 1999). We hypothesized that formation of pores on the cell membrane might lead to $\mathrm{Ca}^{2+}$ influx with detrimental effects on cell survival. Using ratiometric calcium measurements we showed that low concentrations of pneumolysin led to increases in $\left[\mathrm{Ca}^{2+}\right]_{i}$ in the micromolar range. The observed $\left[\mathrm{Ca}^{2+}\right]_{i}$ increases were due to influx of extracellular $\mathrm{Ca}^{2+}$ and did not result from mobilization of intracellular stores (Fig. 3A, 3B, 3C). Our results strongly support the concept that $\mathrm{Ca}^{2+}$ influx is essentially mediated by the pneumolysin pore itself and not via voltage-gated $\mathrm{Ca}^{2+}$ channels (Fig. 4A, 4B). $\left[\mathrm{Ca}^{2+}\right]_{\mathrm{i}}$ following pneumolysin stimulation displayed an oscillating pattern with initial returns to baseline values. Furthermore, chelation of intracellular calcium with BAPTA-AM strongly reduced neuronal cell death by pneumolysin. However, viability of pneumolysin-treated cells was not completely restored by pretreatment with BAPTA-AM probably due to the toxic effects of low intracellular

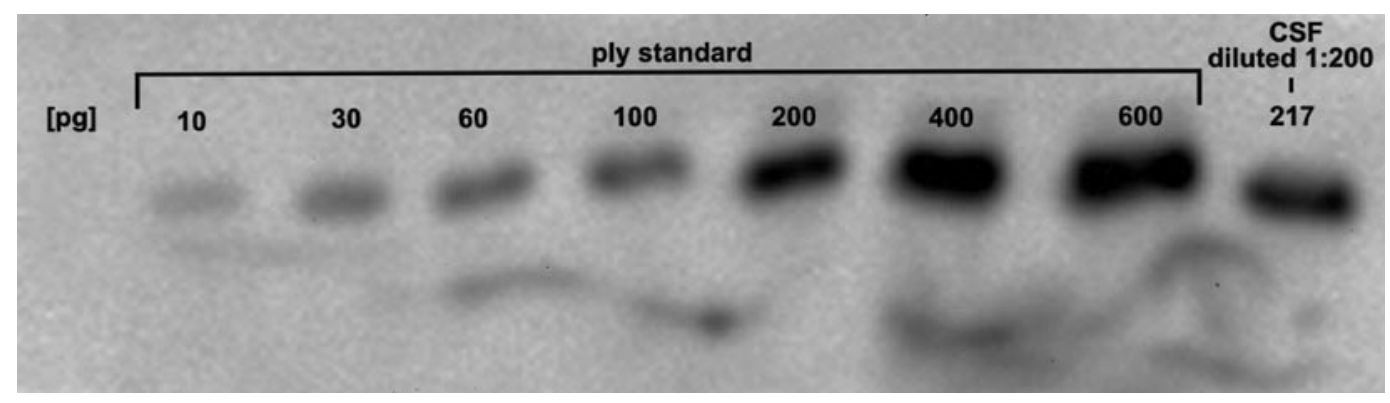

FIG. 8. Presence of pneumolysin in the CSF of experimental animals. Rabbits were inoculated with $10^{6}$ CFU of S. pneumoniae, and CSF was withdrawn at $24 \mathrm{~h}$. Western blotting using a dilution series of purified pneumolysin (ply standard) and a 1:200 prediluted 10- $\mu$ l CSF sample is depicted here. The value obtained from densitometric assessment of concentrations was multiplied by 2000 , yielding a concentration of 4.34 $\mu \mathrm{g} / \mathrm{ml}$ in CSF. 
calcium in SH-SY5Y cells (McGinnis et al., 1999). Pneumolysin pore assembly on cell membranes has been suggested to be a multi-step process involving conformational shifts, aggregation of liposomes, and membrane destabilization (Rossjohn et al., 1998; Bonev et al., 2001). These changes probably lead to variations in the pore's $\mathrm{Ca}^{2+}$ conductivity. This and the action of protective $\mathrm{Ca}^{2+}$ homeostatic mechanisms (Herrington et al., 1996), buffering and extruding $\mathrm{Ca}^{2+}$ from the cell, might account for the observed shape of $\mathrm{Ca}^{2+}$ transients.

Rises in $\left[\mathrm{Ca}^{2+}\right]_{\mathrm{i}}$, most notably through NMDA receptors, have been implicated in the pathogenesis of disorders such as stroke, Alzheimer's disease, Parkinson's disease, and amyotrophic lateral sclerosis (Doble, 1999). $\mathrm{Ca}^{2+}$ influx into cells leads to activation of several molecules including neuronal nitric oxide synthase, CaM kinase II, and MAP kinases (Kawasaki et al., 1997; Mason et al., 1999). We examined the activation of p38 MAPK and demonstrated an increase in phosphorylation as early as $30 \mathrm{~min}$ after stimulation with pneumolysin. Moreover, inhibition of p38 MAPK by its specific inhibitor SB 203580 led to a strong improvement of cell survival. Although dual-specificity kinases, such as MKK3 and MKK6, can directly activate p38 MAPK (Harper \& LoGrasso, 2001), the links between cytoplasmic $\mathrm{Ca}^{2+}$ elevations and p38 MAPK phosphorylation are not known in detail. Calcineurin has been shown to induce p38 MAPK activation following $\mathrm{Ca}^{2+}$ influx in myeloid cells (Lotem et al., 1999). Yet, inhibition of calcineurin with cyclosporin A had no effect on either p38 MAPK activation or cell survival (data not shown).

Opening of the mitochondrial permeability transition (MPT) pore is critical for many types of apoptotic and necrotic cell death and can occur through rises in cytoplasmic calcium (Susin et al., 1998; Crompton, 1999). Bongkrekate, an inhibitor of the adenosine nucleoside translocator, suppresses pneumolysin-induced cell death (present study). Challenge of neurons with either pneumolysin or pneumococcal $\mathrm{H}_{2} \mathrm{O}_{2}$ leads to rises in cytoplasmic calcium and the secretion of apoptosis-inducing factor (AIF) from mitochondria (Braun et al., 2002). These observations demonstrate the central role of mitochondrial damage during direct bacterial neurotoxicity. We also found the broad-spectrum caspase inhibitor $\mathrm{z}$-VAD-fmk to be moderately protective against pneumolysin-induced toxicity, suggesting that caspases are involved in pneumolysininduced cell death. This is in contrast to previous findings (Braun et al., 2001), where direct pneumococcal toxicity to rat primary neurons was caspase inde- pendent. Possibly our use of a human neuronal cell line instead of rat primary cells might account for these differences.

In conclusion, stimulation of neuronal cells with pneumolysin leads to massive $\mathrm{Ca}^{2+}$ influx which is followed by activation of p38 MAPK and probably opening of the MPT pore with consecutive caspase activation. Our data show that neurotoxicity of pneumolysin leads to apoptosis and suggest that it contributes to brain damage observed in pneumococcal meningitis. Concentrations of pneumolysin up to 4.34 $\mu \mathrm{g} / \mathrm{ml}$ can be detected in the CSF of experimental animals $24 \mathrm{~h}$ after induction of meningitis (Fig. 8). Recently, Kerstan et al. (2002) found that pneumolysin reaches concentrations of approximately $200 \mathrm{pg} / \mathrm{ml}$ in patients with meningitis. These findings further corroborate the implications of present study. Pharmacologic intervention to modulate the pneumolysin-initiated cell death cascade in vivo may therefore prove beneficial in a clinical setting.

\section{ACKNOWLEDGMENTS}

This work was supported by grants from the Deutsche Forschungsgemeinschaft to Professor R. Nau and by a grant from Verein zur Förderung von Forschung, Wissenschaft und Lehre der Neurologischen Universitätsklinik Göttingen to Dr. U. Michel.

\section{REFERENCES}

Bonev, B. B., Gilbert, R. J., Andrew, P. W., Byron, O., \& Watts, A. (2001) Structural analysis of the protein/lipid complexes associated with pore formation by the bacterial toxin pneumolysin. J. Biol. Chem. 276, 5714-5719.

Braun, J. S., Novak, R., Gao, G., Murray, P. J., \& Shenep, J. L. (1999a) Pneumolysin, a protein toxin of Streptococcus pneumoniae, induces nitric oxide production from macrophages. Infect. Immun. 67, 3750-3756.

Braun, J. S., Novak, R., Herzog, K. H., Bodner, S. M., Cleveland, J. L., \& Tuomanen, E. I. (1999b) Neuroprotection by a caspase inhibitor in acute bacterial meningitis. Nat. Med. 5, 298-302.

Braun, J. S., Novak, R., Murray, P. J., Eischen, C. M., Susin, S. A., Kroemer, G., Halle, A., Weber, J. R., Tuomanen, E. I., \& Cleveland, J. L. (2001) Apoptosis-inducing factor mediates microglial and neuronal apoptosis caused by pneumococcus. J. Infect. Dis. 184, 1300-1309.

Braun, J. S., Sublett, J. E., Freyer, D., Mitchell, T. J., Cleveland, J. L., Tuomanen, E. I., \& Weber, J. R. (2002) Pneumococcal pneumolysin and $\mathrm{H}_{2} \mathrm{O}_{2}$ mediate brain cell apoptosis during meningitis. J. Clin. Invest. 109, 19-27.

Crompton, M. (1999) The mitochondrial permeability transition pore and its role in cell death. Biochem. J. 341, 233-249.

Crudt, T. J., Usowicz, M. M., \& Henderson, G. (1996) $\mathrm{Ca}^{2+}$ entry followin store depletion in SH-SY5Y neuroblastoma cells. Mol. Brain Res. 36, 93-100. 
Doble, A. (1999) The role of excitotoxicity in neurodegenerative disease: Implications for therapy. Pharmacol. Ther. 81, 163-221.

Gähwiller, B. H. (1981) Organotypic monolayer cultures of nervous tissue. J. Neurosci. Methods 4, 329-342.

Ghatan, S., Larner, S., Kinoshita, Y., Hetman, M., Patel, L., Xia, Z., Youle, R. J., \& Morrison, R. S. (2000) p38 MAP kinase mediates bax translocation in nitric oxide-induced apoptosis in neurons. J. Cell Biol. 150, 335-347.

Gilbert, R. J., Jimenez, J. L., Chen, S., Tickle, I. J., Rossjohn, J., Parker, M., Andrew, P. W., \& Saibil, H. R. (1999) Two structural transitions in membrane pore formation by pneumolysin, the poreforming toxin of Streptococcus pneumoniae. Cell 97, 647-655.

Grynkiewicz, G., Poenie, M., \& Tsien, R. Y. (1985) A new generation of $\mathrm{Ca}^{2+}$ indicators with greatly improved fluorescence properties. J. Biol. Chem. 260, 3440-3450.

Harper, S. J., \& LoGrasso, P. (2001) Signalling for survival and death in neurones: The role of stress-activated kinases, JNK and p38. Cell. Signal. 13, 299-310.

Herrington, J., Park, Y. B., Babcock, D. F., \& Hille, B. (1996) Dominant role of mitochondria in clearance of large $\mathrm{Ca}^{2+}$ loads from rat adrenal chromaffin cells. Neuron 16, 219-228.

Junn, E., \& Mouradian, M. M. (2001) Apoptotic signaling in dopamine-induced cell death: The role of oxidative stress, p38 mitogen-activated protein kinase, cytochrome c and caspases. J. Neurochem. 78, 374-383.

Kawasaki, H., Morooka, T., Shimohama, S., Kimura, J., Hirano, T., Gotoh, Y., \& Nishida, E. (1997) Activation and involvement of p38 mitogen-activated protein kinase in glutamate-induced apoptosis in rat cerebellar granule cells. J. Biol. Chem. 272, 18518-18521.

Kerstan, H., Böttcher, T., Gerber, J., Eiffert, H., Nau, R., \& Spreer, A (2002) Verminderte Freisetzung von Pneumolysin aus Pneumokokken in vitro und in vivo unter Therapie mit Rifampicin und Clindamycin im Vergleich zur Ceftriaxon-Therapie. Abstract accepted at the 75th Kongress der Deutschen Gesellschaft für Neurologie 2002, Mannheim, Germany.

Kim, Y. S., \& Täuber, M. G. (1996) Neurotoxicity of glia activated by gram-positive bacterial products depends on nitric oxide production. Infect. Immun. 64, 3148-3153.

Kim, Y. S., Kennedy, S., \& Täuber, M. G. (1995) Toxicity of Streptococcus pneumoniae in neurons, astrocytes, and microglia in vitro. J. Infect. Dis. 171, 1363-1368.

Ladewig, T., \& Keller, B. U. (2000) Simultaneous patch-clamp recording and calcium imaging in a rhythmically active neuronal network in the brainstem slice preparation from mouse. Pflüeger's Arch. 440, 322-332.

Lotem, J., Kama, R., \& Sachs, L. (1999) Suppression or induction of apoptosis by opposing pathways downstream from calcium-activated calcineurin. Proc. Natl. Acad. Sci. USA 96, 12016-12020.

Maher, P. (2001) How protein kinase C activation protects nerve cells from oxidative stress-induced cell death. J. Neurosci. 21, 2929-2938.

Martin-Blanco, E. (2000) p38 MAPK signalling cascades: Ancient roles and new functions. BioEssays 22, 637-645.

Mason, R. P., Leeds, P. R., Jacob, R. F., Hough, C. J., Zhang, K. G., \& Mason, P. E. (1999) Inhibition of excessive neuronal apoptosis by the calcium antagonist amlodipine and antioxidants in cerebellar granule cells. J. Neurochem. 72, 1448-1456.

McGinnis, K. M., Wang, K. K. W., \& Gnegy, M. E. (1999) Alterations of extracellular calcium elicit selective modes of cell death and protease activation in SH-SY5Y human neuroblastoma cells. J. Neurochem. 72, 1853-1863.
McLaughlin, B., Pal, S., Tran, M. P., Parsons, A. A., Barone, F. C., Erhardt, J. A., \& Aizenman, E. (2001) p38 activation is required upstream of potassium current enhancement and caspase cleavage in thiol oxidant-induced neuronal apoptosis. J. Neurosci. 21, 3303-3311.

Mitchell, T. J., Andrew, P. W., Saunders, F. K., Smith, A. N., \& Boulnois, G. J. (1991) Complement activation and antibody binding by pneumolysin via a region of the toxin homologous to a human acute-phase protein. Mol. Microbiol. 5, 1883-1888.

Mody, I., \& MacDonald, J. F. (1995) NMDA receptor-dependent excitotoxicity: The role of intracellular $\mathrm{Ca}^{2+}$ release. Trends Pharmacol. Sci. 16, 356-359.

Mota, M., Reeder, M., Chernoff, J., \& Bazenet, C. E. (2001) Evidence for a role of mixed lineage kinases in neuronal apoptosis. J. Neurosci. 21, 4949-4957.

Nau, R., \& Brück, W. (2002) Neuronal injury in bacterial meningitis: mechanisms and implications for therapy. Trends Neurosci. 25, 38-45.

Nau, R., Soto, A., \& Brück, W. (1999) Apoptosis of neurons in the dentate gyrus in humans suffering from bacterial meningitis. J. Neuropathol. Exp. Neurol. 58, 265-274.

Ono, K., \& Han, J. (2000) The p38 signal transduction pathway: Activation and function. Cell. Signal. 12, 1-13.

Paton, J. C., Andrew, P. W., Boulnois, G. C., \& Mitchell, T. J. (1993) Molecular analysis of the pathogenicity of Streptococcus pneumoniae: The role of pneumococcal proteins. Annu. Rev. Microbiol. 47, 89-115.

Quagliarello, V., \& Scheld, W. M. (1992) Bacterial meningitis: Pathogenesis, pathophysiology, and progress. N. Engl. J. Med. 327, 864-872.

Rossjohn, J., Gilbert, R. J., Crane, D., Morgan, P. J., Mitchell, T. J., Rowe, A. J., Andrew, P. W., Paton, J. C., Tweten, R. K., \& Parker, M. W. (1998) The molecular mechanism of pneumolysin, a virulence factor from Streptococcus pneumoniae. J. Mol. Biol. 284, 449-461.

Rubins, J. B., \& Janoff, E. N. (1998) Pneumolysin: A multifunctional pneumococcal virulence factor. J. Lab. Clin. Med. 131, 21-27.

Rubins, J. B., Duane, P. G., Clawson, D., Charboneau, D., Young, J., \& Niewoehner, D. E. (1993) Toxicity of pneumolysin to pulmonary alveolar epithelial cells. Infect. Immun. 61, 1352-1358.

Schmidt, H., Tlustochowska, A., Stuertz, K., Djukic, M., Gerber, J., Schütz, E., Kuhnt, U., \& Nau, R. (2001) Organotypic hippocampal cultures: A model of brain tissue damage in Streptococcus pneumoniae meningitis. J. Neuroimmunol. 113, 30-39.

Schuchat, A., Robinson, K., Wenger, J. D., Harrison, L. H., Farley, M., Reingold, A. L., Lefkowitz, L., \& Perkins, B. A. (1997) Bacterial meningitis in the United States in 1995. Active Surveillance Team. N. Engl. J. Med. 337, 970-976.

Smirnov, A. V., Tumani, H., Henne, S., Barchfeld, S., Olgemöller, U., Wiltfang, J., Lange, P., Mäder, M., \& Nau, R. (2000) Glutamine synthetase in experimental meningitis: Increased ration of the subunits 3 and 2 may indicate enhanced activity. Clin. Chim. Acta 292, 1-12.

Stringaris, A. K., Brück, W., Tumani, H., Schmidt, H., \& Nau, R. (1997) Increased glutamine synthetase immunoreactivity in experimental pneumococcal menigitis. Acta Neuropathol. 93, 215-218.

Susin, S. A., Zamzani, N., \& Kroemer, G. (1998) Mitochondria as regulators of apoptosis: Doubt no more. Biochim. Biophys. Acta 1366, 151-165.

Tieu, K., Zuo, D. M., \& Yu, P. H. (1999) Differential effects of staurosporine and retinoic acid on the vulnerability of the SHSY5Y neuroblastoma cells: Involvement of bcl-2 and p53 proteins. J. Neurosci. Res. 58, 426-435. 
Tsien, R. Y., Pozzan, T., Rink, T. J. (1982) Calcium homeostasis in intact lymphocytes: Cytoplasmic free calcium monitored with a new intracellulary trapped fluorescence indicator. J. Cell Biol. 94, 325-334.

van Furth, A. M., Roord, J. J., \& van Furth, R. (1996) Roles of proinflammatory and anti-inflammatory cytokines in pathophysiology of bacterial meningitis and effect of adjunctive therapy. Infect. Immun. 64, 4883-4890.

von Mering, M., Wellmer, A., Michel, U., Bunkowski, S., Tlustochowska, A., Brück, W., Kuhnt, U., \& Nau, R. (2001) Transcriptional regulation of caspases in experimental pneumococcal meningitis. Brain Pathol. 11, 282-295.

Wellmer, A., Noeske, C., Gerber, J., Munzel, U., \& Nau, R. (2000) Spatial memory and learning deficits after experimental pneumococcal meningitis in mice. Neurosci. Lett. 296, 137-140.

Wiltfang, J., Arold, N., \& Neuhoff, V. (1991) A new multiphasic buffer system for sodium dodecyl sulfate-polyacrylamide gel electrophoresis of proteins and peptides with molecular masses 100 000-1000, and their detection with picomolar sensitivity. Electrophoresis 12, 352-366.

Winter, A. J., Comis, S. D., Osborne, M. P., Tarlow, M. J., Stephen, J., Andrew, P. W., Hill, J., \& Mitchell, T. J. (1997) A role for pneumolysin but not neuraminidase in the hearing loss and cochlear damage induced by experimental pneumococcal meningitis in guinea pigs. Infect. Immun. 65, 4411-4418.

Zysk, G., Brück, W., Gerber, J., Brück, Y., Prange, H. W., \& Nau, R. (1996) Anti-inflammatory treatment influences neuronal apoptotic cell death in the dentate gyrus in experimental pneumococcal meningitis. J. Neuropathol. Exp. Neurol. 55, 722-728.

Zysk, G., Schneider-Wald, B. K., Hwang, J. H., Bejo, L., Kim, K. S., Mitchell, T. J., Hakenbeck, R., \& Heinz, H. P. (2001) Pneumolysin is the main inducer of cytotoxicity to brain microvascular endothelial cells caused by Streptococcus pneumoniae. Infect. Immun. 69, 845-852. 